\title{
T lymphocyte subsets studied in a patient with two associated hematologic neoplasias - chronic lymphocytic leukemia $B$ and chronic myeloid leukemia
}

\author{
Subseturile limfocitare $T$ studiate la un pacient cu două neoplazii hematologice \\ asociate - leucemie limfocitară cronică B şi leucemie mieloidă cronică
}

\author{
Georgiana ENE ${ }^{1}$, Ana Maria VLĂDĂREANU² ${ }^{2}$, Horia BUMBEA², Ion DUMITRU ${ }^{1}$ \\ ${ }^{1}$ Clinica de Hematologie, Spitalul Universitar de Urgență, București, România \\ 2Universitatea de Medicină și Farmacie „Carol Davila“, București, România
}

\begin{abstract}
Quantification of various cellular subpopulations facilitates the monitoring of hematological diseases, including chronic lymphocytic leukemia. Variations in the proportions of regulatory $T$ cells in peripheral blood have been described in patients with immune changes such as allergies, autoimmune diseases and haematological diseases such as chronic lymphocytic leukemia. In this article, the Tlymphocyte subsets have been studied using flow cytometry in a patient with two associated hematologic neoplasms. The simultaneous presence of two chronic hematopathies has been confirmed: chronic lymphocytic leukemia (CLL-B) and chronic myeloid leukemia (CML). Chronic lymphocytic leukemia is a frequent malignant hematopathy, a monoclonal expansion of B lymphocytes, while chronic myeloid leukemia is a rare subtype of chronic myeloid leukemia, and the association of the two subtypes is rarely reported in the literature. The following describes the case of a patient diagnosed with chronic lymphocytic leukemia B (LLC-B) who developed during the course of the disease, most likely secondary to the chemotherapy the second hematological neoplasia chronic myeloid leukemia.
\end{abstract}

Keywords: chronic lymphocytic leukemia B, chronic myeloid leukemia, subset T, clinical case

\section{REZUMAT}

Cuantificarea diverselor subpopulații celulare facilitează monitorizarea boliilor hematologice, inclusiv a leucemiei limfocitare cronice. Variații ale proporțiilor celulelor T reglatoare din sângele periferic au fost descrise la pacienți cu modificări imune precum alergii, boli autoimune și boli hematologice precum leucemia limfocitară cronică. În această lucrare au fost studiate cu ajutorul citometriei în flux, subseturile limfocitare T la un pacient cu două neoplazii hematologice asociate. S-a confirmat prezența simultană a două hematopatii cronice: leucemie limfocitară cronică (LLC-B) și leucemie mieloidă cronică (LMC).

Leucemia limfocitară cronică este o hematopatie malignă frecventă, o expansiune monoclonală a limfocitelor $B$, pe când leucemia mieloidă cronică este un subtip rar de leucemie cronică de linie mieloide, iar asocierea celor două subtipuri este rar raportată în literatura de specialitate. In cele ce urmează este descris cazul unui pacient diagnosticat cu leucemie limfocitară cronică $B(L L C-B)$ care a dezvoltat pe parcursul evoluției bolii, cel mai probabil secundar tratamentului chimioterapic cea de-a doua neoplazie hematologică - leucemie mieloidă cronică.

Cuvinte cheie: leucemie limfocitară cronică B, leucemie mieloidă cronică, subseturi T, caz clinic 


\section{INTRODUCERE}

Prezența concomitentă a două clone care reprezintă și 2 linii celulare diferite (linia limfoidă și mieloidă) și anume leucemia limfocitară cronică și leucemia mieloidă cronică-faza cronică cel mai probabil secundară chimioterapiei, la același pacient este extrem de rar ntâlnită [1]. Leucemia limfocitară cronică cu celulă B (LLC-B) este constituită dintr-o populație clonală de celule B CD19+CD5+, care se găsesc înprimul rând însângele periferic, și este una dintre cele mai frecvente afecțiuni hematologice îrtâlnite la adulții din Occident, cu o incidență estimată la aproximativ 4,5 cazuri noi la 100.000 de persoane anual [2], vârsta mediană la momentul stabilirii diagnosticului fiind considerată n prezent de 72 ani, aproximativ $10 \%$ dintre pacienții cu LLC au sub 55 ani. Riscul apariției LLC crește progresiv cu vârsta, este de 2 ori mai mare la bărbați decât la femei, iar membrii familiei pacienților cu LLC moștenesc un risc genetic de 6 pana la 9 ori mai mare [3].

Boala prezintă o evoluție clinică heterogenă, unii pacienți au o evoluție a bolii indolentă, fără a necesita tratament pe când la alții boala debutează agresiv și necesită inițierea tratamentului imediat sau îtr-un viitor apropiat. Pacienții cu LLC pot avea transformări ale bolii n limfom non-Hodgkin, limfom Hodgkin sau leucemie prolimfocitară sau pot dezvolta secundar un al doilea neoplasm solid, cu toate acestea dezvoltarea leucemiei mieloide cronice asociate terapiei este o situație neobișnuită.

\section{PREZENTAREA CAZULUI}

Pacient $\mathrm{n}$ vârstă de 61 ani, sex masculin, mediul urban, cu multiplă patologie cardiacă asociată (ICC clasa II-III NYHA, fibrilație atrilă cu AV rapidă, HTAP secundară moderată, cardiomiopatie dilatativă, TVNS recurente), este diagnosticat $n$ martie 2011 cu leucemie limfocitară cronică stadiul I forma hiperleucocitară, conform clasificării Rai, respectiv stadiul $A$ conform clasificării Binet, $c u$ semne B de boală (scădere ponderală și transpirații nocturne). La debut, mutația TP53 a fost efectuată, fiind negativă.

La momentul respectiv, s-a decis inițierea tratamentului chimioterapic, tip FC (fludarabină și ciclofosfamidă), pacientul efectuând o singură aplicație tip FC, ulterior refuzând continuarea tratamentului din cauza efectelor adverse. Pacientul este pierdut din evidență până înanul 2013, când se prezintă cu progresie de boală, se reinițiază tratament chimioterapic tip R-FC. Pacientul tolerează cu greu primele 2 aplicații, refuză continuarea tratamentului, nu se mai prezintă la controalele periodice următoare, optând pentru medicină alternativă.

În perioada noiembrie 2018 - ianuarie 2019, prezintă spitalizări repetate în cadrul spitalului de boli infecțioase cu sindrom febril persistent, unde este diagnosticat cu pneumonie. În luna februarie 2019, se prezintă în cadrul secției de hematologie cu progresie de boală, de la stadiul I Rai la stadiul III Rai, cu stare generală mediocră, prezentând clinic adenopatii superficial palpabile axilar bilateral cu diametru $2-3 \mathrm{~cm}$, splenomegalie tumorală (CT diametru antero-posterior $19,5 \mathrm{~cm}$, iar cel craniocaudal $24 \mathrm{~cm}$ ). Hemoleucograma a relevat leucocitoza cu limfocitoză ( $L=267.000 / \mathrm{mmc}$, Limf $=99 \%$ ), anemie moderată $(\mathrm{Hb}=9 \mathrm{~g} / \mathrm{dl})$, trombocitoză $(\mathrm{Tr}=$ $813.000 / \mathrm{mmc}$ ). Pe frotiul de sânge periferic se decelează formulă desfășurată cu bazofile și eozinofile care ridică suspiciunea de sindrom mieloproliferativ cronic. În urma investigațiilor efectuate (examen molecular BCR-ABL calitativ, examen citogenetic (fig. 1), biopsie osteomedulară), se confirmă o a doua neoplazie hematologică - leucemia mieloidă cronică - faza cronică.

Din martie 2019, se inițiază tratament chimioterapic conform protocolului ObinutuzumabLeukeran pentru leucemia limfocitară cronică. Având în vedere patologia cardiacă a pacientului, se decide temporizarea tratamentului cu inhibitor de tirozinkinază (TKI) pentru leucemia mieloidă cronică.

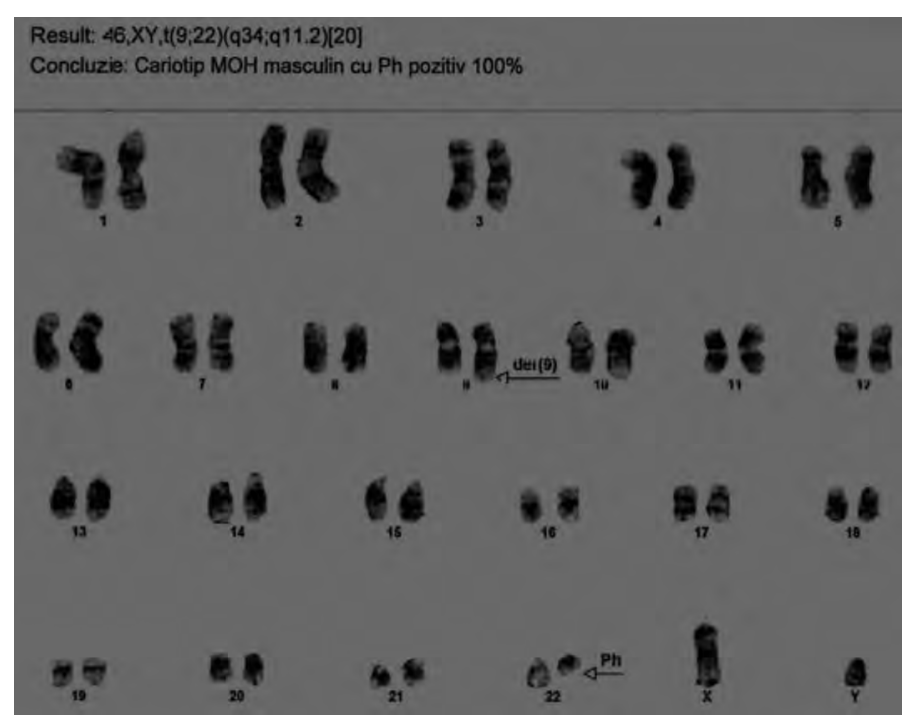

FIGURA 1. Cariotipul obținut la examenul citogenetic

\section{NIVELUL CELULELOR T REGULATORII}

Analiza citometrică de flux a fenotipurilor limfocitelor din sângele periferic s-a dovedit un instrument extrem de util în gestionarea unei game 
largi de neoplazii hematologice, inclusiv leucemia limfocitară cronică. La acest pacient s-a folosit citometrie de flux multiparametric cantitativ și s-au determinat nivelurile absolute și proporționale ale unei serii de fenotipuri, care au inclus celulele Treg CD3+/CD4+/CD25+ activate, FoxP3+, Heliost, celule CD45RA+ și subseturile T din sângele periferic.

Nivelurile celulelor Treg au fost analizate înainte de inițierea tratamentului chimioterapic tip Obinutuzumab+Leukeran și după administrarea a 3 cicluri de tratament. Înainte de inițierea tratamentului, în martie 2019, s-au observat niveluri crescute ale celulelor $\mathrm{T}$ activate $\mathrm{CD} 3+/ \mathrm{CD} 4+$ / CD25+ și niveluri scăzute ale celulelor T naive helper CD45RA+ față de nivelurile de referință din literatura de specialitate pentru o gamă largă de fenotipuri ale limfocitelor din sângele periferic aplicabile populației adulte sănătoase [4]. Aceste expresii au fost analizate și după 3 cicluri de chimioterapie în iunie 2019, când s-a observat scăderea valorilor (tabel 1).

În urma acestei comparații, s-a putut observa o asociere dintre frecvențele celulelor Treg CD4 și răspunsul pacientului la terapie. La 3 luni de tratament, numărul total de celule T CD4 prezente în sângele periferic au fost semnificativ mai mic, acest fapt pare să se coreleze cu răspunsul pacientului la tratament.

TABELUL 1. Numărul total de celule T CD4 prezente în sângele periferic

\begin{tabular}{|l|l|l|}
\hline Celule T reg CD3+ CD4+ \% & Martie 2019 & Iunie 2019 \\
\hline CD25+ \% & 7\% & $3,4 \%$ \\
\hline FoxP3+ \% & $5,9 \%$ & $0,5 \%$ \\
\hline Helios+ \% & $3,5 \%$ & $0,4 \%$ \\
\hline Naive helper - CD45RA+ \% & $3,5 \%$ & $2,4 \%$ \\
\hline Efector memory - CD39+ \% & $5,3 \%$ & $1,3 \%$ \\
\hline
\end{tabular}

Funcția celulelor $\mathrm{T}$ reglatoare, care exprimă Foxp3 și CD25 +, este de a suprima activarea, proliferarea și funcțiile celulelor efectoare ale sistemului imunitar. Împreună cu CD4 și CD25, expresia factorului de transcripție FoxP3 este considerată semnul distinctiv al celulelor $\mathrm{T}$ reglatoare umane (CD3+, CD4+, CD25+, FoxP3+).[5] Helios, un factor de transcripție al familiei Ikaros, a fost descris ca un marker care identifică timusul - nTreg derivate -, spre deosebire de Treg-urile induse în țesuturile periferice (iTregs). În plus, Helios acționează ca un potențiator al funcției de reglementare [6].

Expresia de suprafață a ectoenzimei CD39 exercită o funcție de suprimare prin activitatea sa ATP și este restricționată la o subpopulație ca Treg efector / memorie [7]. Expresia de suprafață CD45RA indică o subpopulație naivă sau neinițiată de Tregs [8]. CD27 este exprimat de celule T naive cu rol activator, care pierd expresia CD27 atunci când devin efectoare. Acest marker împarte clar populația de memorie în două grupuri și subliniază diferitele profiluri funcționale ale populațiilor de memorie CD27 + și CD27-, în ceea ce privește exprimarea capacității de a răspunde la antigen [9].

În luna august au fost analizate și subseturile limfocitare $\mathrm{T}$ la acest pacient, care au relevat, niveluri crescute ale expresiei celulei T helper CD4+ și niveluri scăzute ale celulelor T supresor CD8+, în comparație cu valorile de referință din literatură, de exemplu Bisset și colab. [4] (tabel 2).

TABELUL 2. Valori de referință subseturi limfocitare [4]

\begin{tabular}{|l|l|l|}
\hline \multicolumn{1}{|c|}{$\begin{array}{c}\text { Subseturi limfocitare } \\
\text { pacient }\end{array}$} & $\begin{array}{c}\text { Valori } \\
\text { pacient }\end{array}$ & $\begin{array}{c}\text { Valori de referință } \\
\text { (Bisset și colab.) }\end{array}$ \\
\hline Helper CD4+ & $74 \%$ & $\begin{array}{l}47, .95 \% \\
(32,53-62,88)\end{array}$ \\
\hline Supresor CD8+ & $23 \%$ & $\begin{array}{l}23,20 \% \\
(11,55-38,60)\end{array}$ \\
\hline T naive CD197/CCR7 & $58,33 \%$ & \\
\hline $\begin{array}{l}\text { Ag specific efectoare CD27 } \\
\text { neg si CD28 poz }\end{array}$ & $21,2 \%$ & \\
\hline $\begin{array}{l}\text { Central memory CD45RA- } \\
\text { CCR7+ }\end{array}$ & $1,8 \%$ & \\
\hline $\begin{array}{l}\text { Efectoare memory } \\
\text { CD45RA-CCR7- }\end{array}$ & $70,7 \%$ & \\
\hline Efectoare CD57+ & $58,3 \%$ & \\
\hline Inhibitoare CD279/PD-1+ & $4 \%$ & \\
\hline
\end{tabular}

\section{MATERIALE ŞI METODE}

Pentru testare s-a folosit sânge periferic recoltat pe EDTA, cu depozitare la temperatura camerei. Pentru marcare s-au folosit kiturile BC DuraClone. BCDuraClone IMT cell subsets: CD45RA-FITC (clone 2H4), CD197-PE (clone G043H7), CD28-ECD (cloneCD28.2), CD279-PECy5.5 (clone PD1.35), CD27-PECy7 (clone 1A4.CD27), CD4-APC (clone 13B8.2), CD8-AF700 (clone UCHT-1), CD57-PacB (clone NC1), CD45-KrO (clone J33) cu protocol Lyse-Wash cu BD FACS Lyse. Și BC DuraClone IM Treg: CD45RA-FITC (clone 2H4LDH11LDB9 (2H4)), CD25-PE (clone B1.49.9), CD39-PECy5.5 (clone BA54), CD4-PECy7 (clone SFCl12T4D11 (T4)), FoxP3-AF647 (clone UCHT-1), Helios-PacB (clone Helios peptide (aa51-107)), CD45-KrO (clone J33), prelucrat cu kitul PerFix-nc pentru permeabilizare FoxP3. Citirea probelor a fost realizata pe instrumentul BC Gallios în urma stabilirii voltajelor optime folosind protocolul Harmonemia și bile de calibrare Spherotech Rainbow Calibration Particles (8 Peaks) 3,41 um. Pentru fiecare tub s-a realizat citirea a minim 100.000 evenimente. 


\section{REZULTATE}

În urma citirii achizițiilor, în prealabil s-a procedat la îndepărtarea dubleților și resturilor celulare prin folosirea de porți tip FSC-A/FSC-H pentru excludere dubleți, și FSC-A/SSC-A pentru excludere resturi celulare, iar selectarea limfocitelor s-a realizat în funcție de SSC-low CD45high, din care s-a selectat populația CD3+, CD4+ (limfocite T helper) (fig. 2).
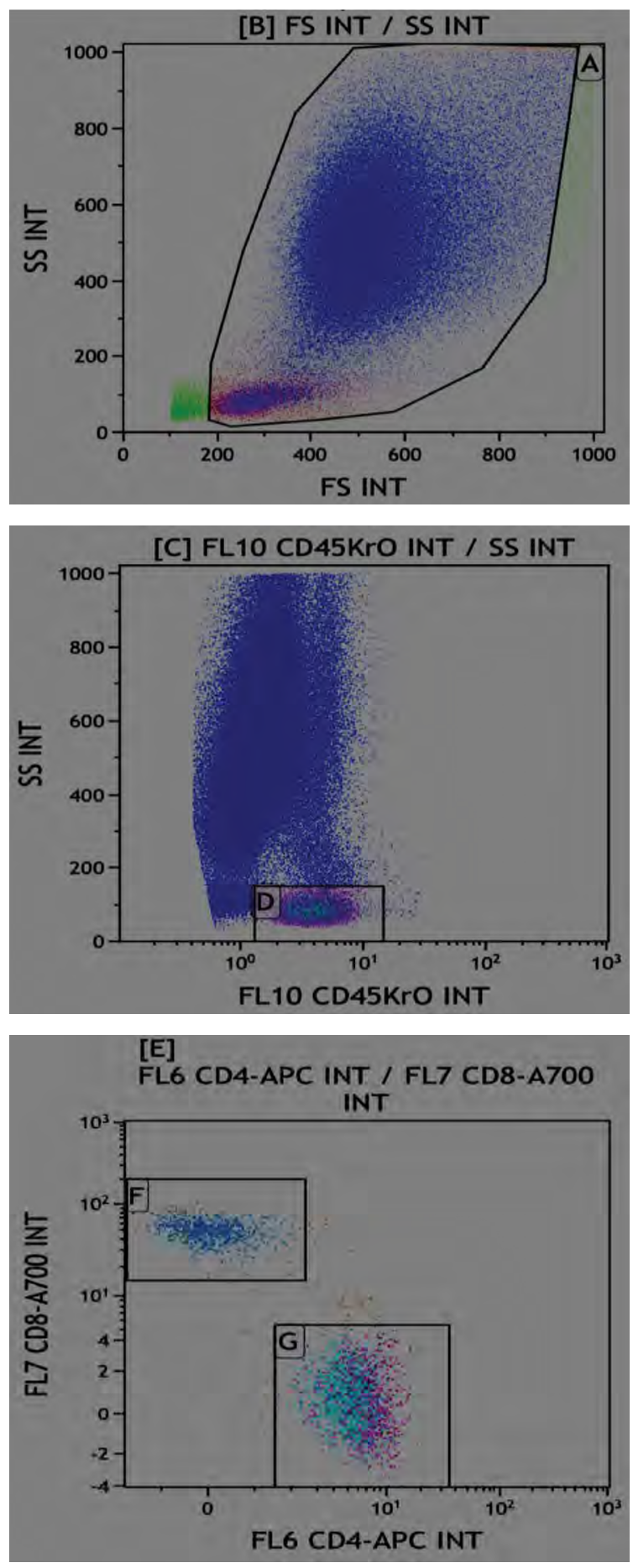

FIGURA 2. Îndepărtare dubleți și debriuri, selecție limfocite TCD4
Pentru tubul BC DuraClone IM subseturile limfocitare $T$ s-au subîmpărțit în celule centrale de memorie și/sau naive în funcție de expresia CD197/CD45RA și subtipul CD27 (fig. 3).
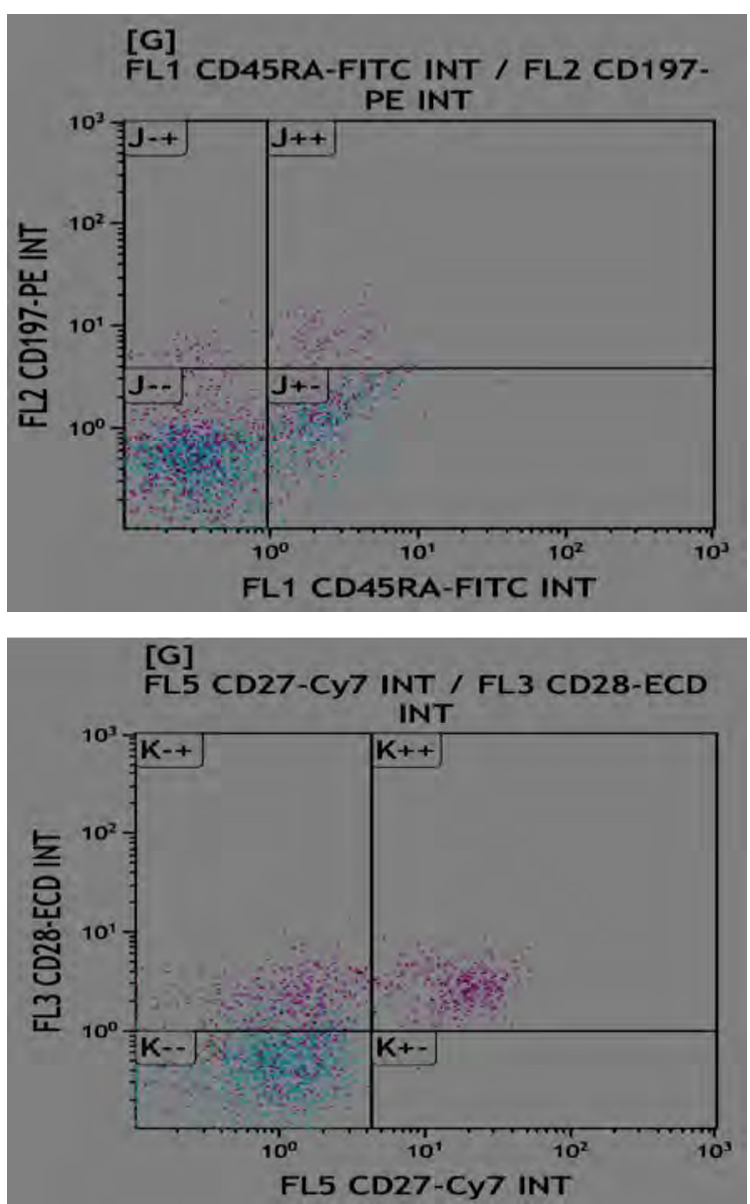

FIGURA 3. Selecție a principalelor subpopulații CD4

Pentru tubul BC DuraClone IM Treg s-au selectat fracțiunea CD4+, CD25 bright (Th activate) și în mod special subfracțiunea FoxP3, cât și limfocite T CD4+ CD39+ (efectoare de memorie) (fig. 4).

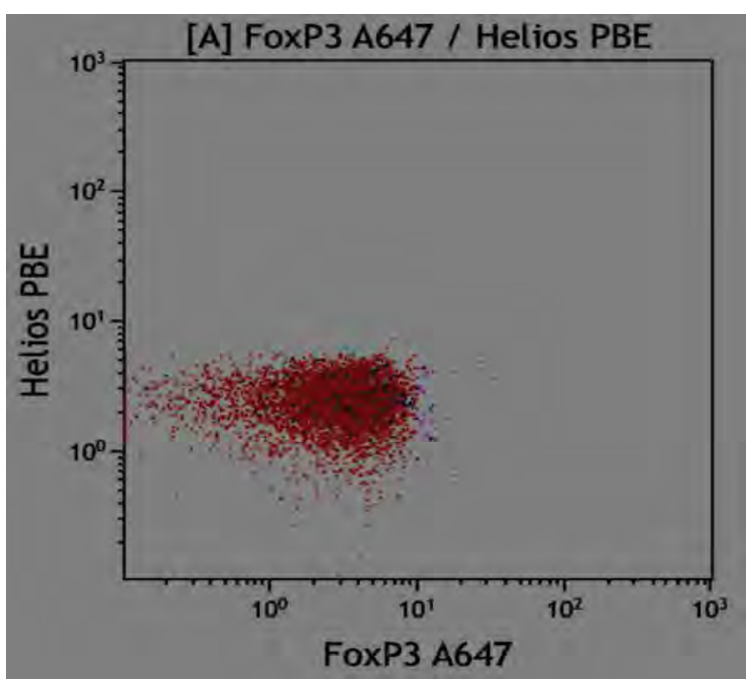



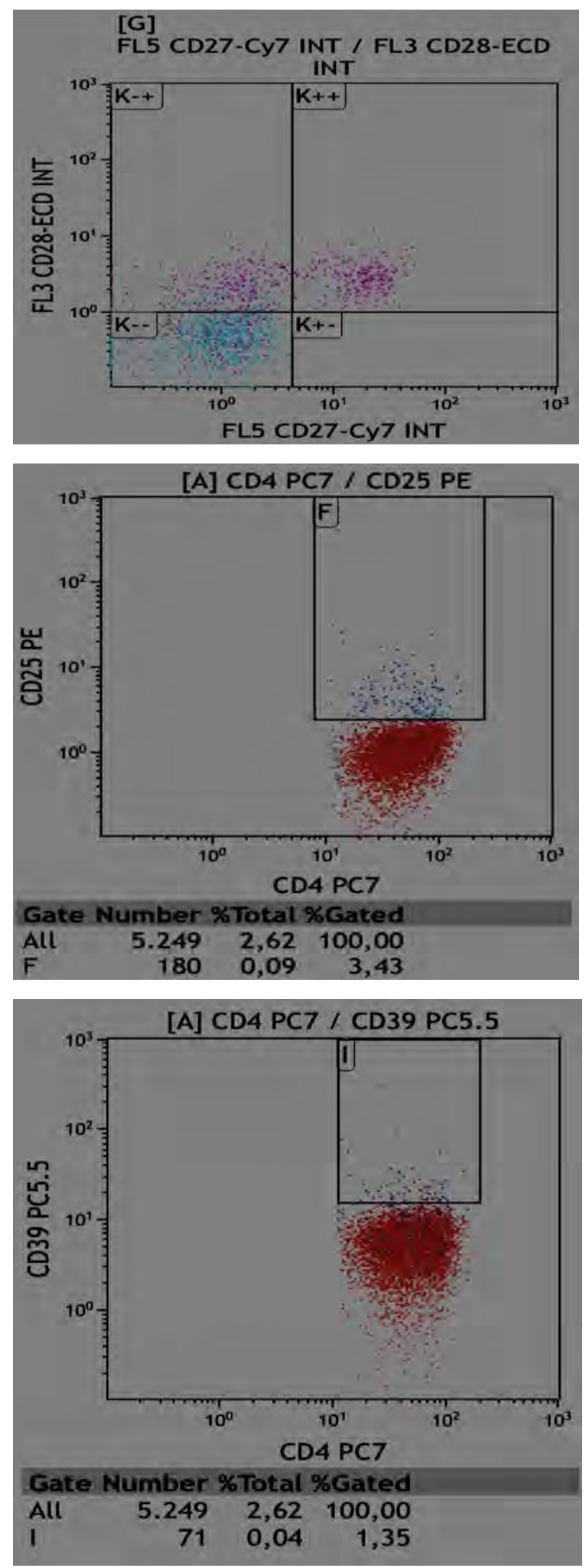

FIGURA 4. Selecție subpopulații limfocite Thelper

\section{DISCUȚII}

Cazurile în care leucemia limfocitară cronică coexistă cu leucemia mieloidă cronică sunt rarisime. Cea de-a doua neoplazie poate să apară în evoluția LLC numai în cazuri rare și pare să fie lega- tă de terapie pe fondul imunosupresiei prelungite. În cazul nostru am considerat că prezența clonei de LMC este secundară chimioterapiei, cu analogi nucleozidici (Fludarabina) și cu agenți de alchilare (Endoxan). În literatura de specialitate probabilitatea dezvoltării clonei de LMC este scăzută dacă pacientul este tratat doar cu monoterapie, adică doar cu agenți alchilanți sau analogi nucleozidici, însă riscul crește dacă ambii se administrează la același pacient, așa cum s-a întâmplat și-n cazul nostru. Prognosticul la acest tip de cazuri este rezervat, cu răspuns minim la tratament, toxicitate hematologică crescută și durata de supraviețuire scăzută, la care se adaugă toxicitatea cardiacă.

În ceea ce privește subseturile limfocitare $\mathrm{T}$, am putea face observația că celulele $T$ de reglementare au rol în supresia imunității, iar chimioterapia potențează rolul lor imunosupresor, acest lucru corelându-se cu răspunsul terapeutic al pacientului. Spre exemplu răspunsul hematologic și clinic obținut de pacient după 3 cicluri de chimioterapie (scăderea cu $50 \%$ a leucocitozei și limfocitozei, diminuarea adenopatiilor periferice, ameliorarea semnelor B de boală) se poate corela în mod direct cu modificarea micromediului sistemului imun $T$ (diminuarea cantitativă/raport celule T CD4 helper, naive și efector). Însă la acest pacient trebuie luat în calcul și ce-a de-a doua neoplazie pentru care nu s-a inițiat tratament specific și care poate influența variațiile procentuale ale subseturilor limfocitare T, în acest sens dovadă fiind subseturile $\mathrm{T}$ (tabelul 2), care prezintă valori crescute ale celulelor Th CD4+ și valori ușor scăzute ale celulelor T supresor CD8+, după 3 cicluri de chimioterapie.

De asemenea, de menționat este că pacientul a fost testat pentru mutația TP53 și la diagnostic și înainte de reinițierea tratamentului Obinutuzumab-Leukeran care a fost negativă, iar testarea PCR- hipermutație somatică în regiunea IGHV a prezentat status IGHV mutant care este caracterizat de un prognostic favorabil.

\section{CONCLUZII}

Intervalele obținute pentru subseturile de limfocite $\mathrm{T} C D 3+$, respectiv subseturile $\mathrm{CD} 4+$, la populațiile LLC ar putea permite o monitorizare îmbunătățită, precum și o strategie terapeutică optimizată pentru pacienții cu LLC, cu diminuarea toxicității hematologice. Identificarea markerilor care caracterizează subpopulațiile celulare cheie ar putea permite o înțelegere mai cuprinzătoare a cursului natural al răspunsului sistemului imun față de imunopatogeneza LLC. 


\section{BIBLIOGRAFIE}

1. Michele Gottardi, Valter Gattei, Massimo Degan, Riccardo Bomben, Antonella Zucchetto et al. Concomitant chronic lymphocytic leukemia and acute myeloid leukemia: Evidence of simultaneous expansion of two independent clone. Leukemia \& Lymphoma, May 2006; 47(5): 885-889.

2. Elisa ten Hacken, Jan A. Burger. Microenvironment interactions and B-cell receptor signaling in chronic lymphocytic leukemia: Implications for disease pathogenesis and treatment. Biochimica et Biophysica Acta (BBA), Molecular Cell Research Volume 1863, Issue 3 March 2016, Pages 401-413.

3. B. Eichhorst,T. Robak, E. Montserrat, P. Ghia, P. Hillmen, M. Hallek, C. Buske. Chronic lymphocytic leukemia: ESMO Clinical Practice - Guidelines for diagnosis, treatment and follow-up. Annals of
Oncology 2015; 26 (Supplement 5): v78-v84.

4. Bisset LR, Lung TL, Kaelin M, Ludwig E, Dubs RW. Reference values for peripheral blood lymphocyte phenotypes applicable to the healthy adult population in Switzerland. Eur J Haematol 2004: 72: 203-212.

5. Klaus G. Schmetterer, Alina Neunkirchner, Winfried F. Pickl. Naturally occurring regulatory $T$ cells: markers, mechanisms, and manipulation. FASEB J. 2012 Jun; 26(6):2253-76.

6. Xiaohong Lin, Maogen Chen, Ya Liu, Zhiyong Guo, Xiaoshun He, David Brand, Song Guo Zheng. Advances in distinguishing natural from induced Foxp3+ regulatory T cells. Int J Clin Exp Pathol. 2013.

7. Silvia Deaglio, Karen M. Dwyer, Wenda Gao, David Friedman, Anny Usheva, Anna Erat, Jiang-Fan Chen, Keiichii Enjyoji, Joel
Linden, Mohamed Oukka, Vijay K. Kuchroo, Terry B. Strom, Simon C. Robson. Adenosine generation catalyzed by CD39 and CD73 expressed on regulatory $T$ cells mediates immune suppression. J Exp Med, Jun 112007.

8. Valmori D, A Merlo, NE Souleimanian, CS Hesdorffer, M Ayyoub. A peripheral circulating compartment of natural naive CD4 Tregs. J. Clin. Invest. 2005 (115): 1953-1962.

9. Åsa Schiött, Malin Lindstedt, Bengt Johansson-Lindbom, Erwin Roggen, Carl AK Borrebaeck. CD27- CD4+ memory T cells define a differentiated memory population at both the functional and transcriptional levels Immunology. 2004 Nov; 113(3): 363-370. 